\title{
Improving Students' Speaking Performance By Using Autoplay Media At SMAS Darul Hikmah Mataram
}

\author{
Agus Salim ${ }^{1}$, Edi Firman², Yusratun Rosida ${ }^{3}$ \\ ${ }^{123}$ English Language, Faculty of Language and Art (FPBS) IKIP Mataram \\ agussalim@ikipmataram.ac.id, yusrarosida97@gmail.com
}

\begin{abstract}
This research was aimed to describe using Autoplay Media to Improve Students' Speaking Performance at SMAS Darul Hikmah Mataram. The model of this research was classroom action research. This research focused on improving of the students' speaking performance by using Autoplay Media. This research consisted of one cycle include the classroom action research model such as: planning, acting, observing, and reflecting. In this research, the researcher toke the XI IPS of SMAS Darul Hikmah Mataram. The instrument that used by the researcher in this study were test, recording, and observation sheet to measure the students result. Based on the result of data analysis the mean score of students' achievement in the first cycle was 45.05 in the pre-test and the percentage was $21.05 \%$ and post-test was 79.36 , percentage was $78.94 \%$. So the researcher concluded that the score of the students' speaking performance was higher than minimum Complete Criteria Success (KKM), in which the KKM of SMAS Darul Hikmah Mataram was 75. So, it could be concluded that this research was successful and could increase students' speaking performance.
\end{abstract}

Key Words: Speaking Performance, Autoplay Media.

\section{INTRODUCTION \\ Background of Study}

English language is one of international language in which used to communicate each other. Basically English language has four skills instead namely listening, writing, reading, and speaking. Those four skills are very important to learn if we want to comprehend the English language itself.

Actually all those skills are related each other. But because this research focused on speaking skill so, more we talk about speaking itself. Speaking is one of the most important part in language, because without speaking we suppose to be difficult to show up our ideas to someone else clearly. By speaking we able to make direct interaction so we can understand each other.

Based on the observation on 10 until 13 December 2018 at SMAS Darul Hikmah Mataram there some problem that found by the researcher especially in XI SMA IPS students are they were difficult to determine the words dealing with the foreigner attempting in their language, the students difficult to control their confident because sometimes they still think about grammatical structure, the students also lake in vocabularies so that they were difficult to show up their ideas. The last problemwas dealing with the teacher's strategy in teaching, in which there is no such strategy or even media that can support the learning process easily.

Based on the students' problems, the researcher solved it by using Auto lay Media to improve students' speaking performance. Auto play Media is kind of media software that include many files inside of it like picture, video, audio, or even quiz.

\section{Definition of Speaking}

According to Brown, (2004: 140) Speaking is productive skill that can be directly and empirically observed, those observations are invariably colored by the accuracy and effectiveness of a test-takers listening skill, which necessarily compromises the reliability and validity of an oral production test.

According to Luoma, (2004: 9) Speaking is an integral part of people's daily lives. Speaking is one of the way to make an active communication in every activities. 
Without speaking everything should not be well, because nobody can catch the meaning of your mind set. Speaking is the most important part in doing anything. Having an oral communication is the best way to interact with the other people. It could be an active interaction because one another directly catch the speaker's meaning.

According to Huges, (2003: 131-132) there are five indicators of speaking such as:

1) Pronunciation

Can be intelligible though, good spelling, dealing with foreigners attempting to speak his language.

2) Grammar

Confident control of the grammar, able to speak the language with sufficient structural accuracy.

3) Vocabulary

Has speaking vocabulary sufficient to express him simply with someone circumlocutions, able to speak the language with sufficient vocabulary in conversation.

4) Fluency

Can discuss particular interest of competence, able to use the language fluently on all levels, can participate in any conversation with fluency.

5) Comprehension

Understand a normal rate of speech, can understand questions and statement with paraphrase, can get the gist of most conversation of nontechnical subject.

\section{Definition of Auto play Media}

According to Khairun, (2017: 15) Auto play media is an interactive media that can attract the attention of students. This media also an easy media to use, because it is not use the difficult language program so everybody can understand how to use this media. Autoplay media is not just help the students to understand well about the lesson itself, but also can help the teacher to explain the material in structured and simple. This media also train the teacher to be creative and innovative to choose the types of good media that suitable for their students.
Based on the explanation above, it can be concluded that autoplay media is one of the teacher's solution to use in teaching the students effectively, because the autoplay media also can attract the students' attention to focus in learning process and the students can enjoy it by seeing the picture, video or even audio that they ever listen.

\section{Procedures of Autoplay Media}

1) Open the autoplay application

2) Click the new project

3) Click (control+sift+enter)

4) Make the home page

5) Design the home page

a) Click the icon new button object

b) Choose the icon based on what we want

c) Click ok

d) Give the name to the icon that we have been chosen

e) Click ok

6) Copy paste the home knob

7) Change the name of home knob that we have been copied to the other files name based on our peripheral study

8) Make the exit scrip

9) Duplicate the home page

10) Upload or arrange the peripheral study based on their place that we have made

11) Check the media that we have arrange by click the F5.

\section{Research Method}

In this research, the researcher used Classroom Action Research (CAR) with qualitative and quantitative approach. Quantitative data taken by the speaking test. The quantitative data analysis used to know elicit performance from learners with the purpose of measured their attainment of specified criteria. Qualitative data included virtually any information that could be captured that was not numerical in research, and in this study the researcher use the data condensation to get the data analysis. In which the researcher records the students' voice when they are show their ideas about something orally in front of the class.

According to Costello (2003: 5) stated there are 4 steps in classroom action research such 
as planning, acting, observing and reflecting

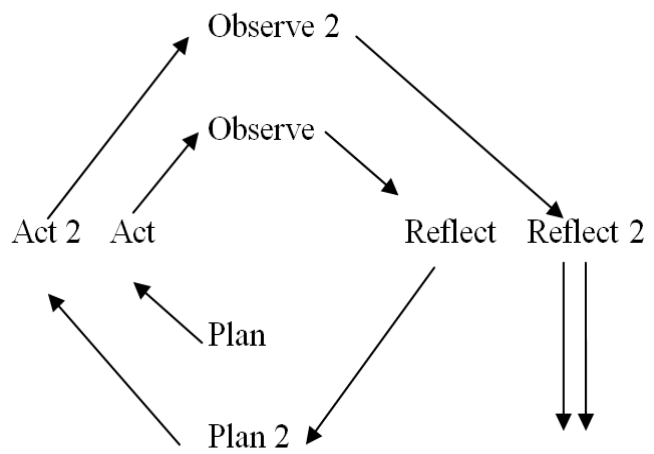

Figure

3.1 An extended action research model (Costello, 2003: 5).

\section{Setting of the Research}

1. Place of the research

This research was be held at second grade students of SMAS Darul Hikmah Mataram in academic year 2018/2019.

2. Time of the research

This research was being held one month or 4 weeks. Every week the researcher takes two meeting and this research use $2 \times 40$ minutes in each meeting. In which one meeting that based on English schedule on Monday and one meeting more from the extra circular class on Saturday afternoon. So the total meeting in one month is eight meetings.

\section{Subject and Object of the Research}

1. The Subject of the Research

The subject was just one class at the second grade students of SMAS Darul Hikmah Mataram with the participant 19 students of XI SMA IPS class, they were 12 female and 7 male. The researcher choose that class because the researcher was conducted the teaching practice at that classroom so the researcher have already known well about the character, condition and situation of those students.

2. The Object of the Research

The object in this research was Autoplay media toimprove students' speaking performance.

\section{Instruments of the Study}

In this research, the researcher used some instrument to know the students' development, as follow:

1. Speaking Test

The test that given to the students to know the students' speaking performance. The researcher gives the students test by dividing the students picture and ask them to describe it orally based on their understanding. In which the researcher assess the students' result based on the indicator of speaking itself and use this following formula by Henning in sukar's thesis $(2017: 30)$

$$
\mathrm{Y}=\underline{\mathrm{X}} \mathrm{C}
$$

Where:

$\mathrm{Y}=$ The percentage score

$X=$ The raw score (the number of correct items)

$\mathrm{C}=$ The total number of items (the highest possible score)

2. Observation Sheet

a. Teachers' observation sheet

Teacher observation sheet conducted when the teaching learning process, in order the researcher knows the teacher activities on how the teacher cross or convey their material during teaching and learning process happened.

b. Students' observation sheet

Students' observation sheet was the students' activities that watch by the researcher during teaching and learning process happened in the classroom, does the students active, passive, dizzy, or feel bored when join the teaching and learning process.

\section{Recording}

Recording was one of the instrument that used by the researcher to collect the data from the students. In which the researcher records the students' voice during the students performed their ideas orally in front of the class. 


\section{Procedures of the Research}

In this research the learning process was design from action research. Every step conduct to improve students' speaking performance. The process of action research consist of planning, acting, observing, and reflecting, as follow:

1. Preliminary of the study

In conducting the preliminary of study it means that givingtheinformation about teaching's model used the autoplay media itself. Whenlearning process the researcher observe students' problem by having an interview with an English teacher of SMAS Darul Hikmah Mataram. In which in the end the researcher can adopt the student's problem in general.

2. Planning

In this activity, the researchers prepare some preparations before conduct the research, as follow:
a) Syllabus
b) Lesson plan
c) media
d) Material
e) Instruments

3. Acting

The second stage after planning was acting, which aimed to apply autoplay media and the lesson plan that has been made. The teacher implement the autoplay media that have been made while the researcher as the observer inside the classroom itself.

4. Observing

The next part was observing, which in this part the researcher observed the students' behavior toward the autoplay media during the teaching and learning process. The researcher also observed the result of the test whether it was improved or not. Based on that observations, the researcher used the observation sheets that consist of students' and teachers activities in the classroom:

a. Students' Activity

The students' activities observed by the researcher include: respond the teacher greeting, listen carefully what the teacher explain in front of the class, respond the question that give by the teacher, etc.

b. Teachers' activity

The teachers' activities also observed by the researcher include: Teacher greeting, checks condition of students', checks students' attendance, gives the materials, showing the media inside the autoplay itself, giving question or quiz, make evaluation about the materials, concluding the lesson, and closing the lesson.

\section{Reflecting}

In this activity, the researcher applied the reflecting from those actions in cycle. The researcher analyzed the students' activity and the teacher's activities. In which there was improvement of students' speaking performance in cycle 1 so the researcher no need to continue to the next cycle. The researcher can say the research is success if the students' percentage scores higher that KKM value of the school itself. The KKM score of SMA Darul Hikmah Mataram is 75.

\section{Techniques of Data Collection}

Technique of data collection in this research used quantitative and qualitative data. In this research the researcher use three kinds of technique to collecting data. Such as test, observation sheet, and recording. The explanation as follow:

1. Test

There are two types of test used to collect the data by the researcher. In this research the researcher used pre-test and post-test. Pre-test was do at the beginning before do an action and post-test done after an action. Both of test that used in this test, it was purpose to know students' speaking performance.

2. Observation Sheet

This observation sheet used to know teacher and students' activities in learning process. The researcher provide the teacher and students observation sheet as the instrument to collect the data. The observation sheet was purpose to obtain the information from teacher and students. 
3. Recording

: Total of students

Recording used to know the students ability in speaking. The researcher used the recording because by recording that can support the real data from the students' speaking test. By listening the students' recording, the researcher can analyze and correct the students' result itself. Recording also types of data condensation that inside of qualitative method that used by the researcher in this study, so it will related each other.

\section{Techniques of Data Analysis}

The researcher used the quantitative and qualitative approach as the technique of data analysis. The qualitative analysis gathered from the observation sheet and recording, in which the researchers analyze the result of the observation sheet and recording itself to get the data. While the quantitative gathered through the test that given by the researcher include the pre-test and post-test. Because the quantitative is dealing with numerical statistic so, the researcher get the data from the students' pre-test and post-test score instead. Here is the way on how the researcher analyzes the data using the quantitative approach.

\section{Quantitative Data}

$$
\mathrm{Me}=\frac{\sum x i}{n}
$$

\section{Where:}

$\mathrm{Me}=$ Mean (the average of the test result)

$\sum=$ Epsilon (read the amount)

$\mathrm{Xi}=$ The value of $\mathrm{x}$ to $\mathrm{i}$ until $\mathrm{n}$

$\mathrm{n} \quad=$ The total number of the students (Sugiyono, 2007: 49)

The next step was to know the percentages of students' score who pass the KKM. It was calculated as followed:

Where:

$$
\mathrm{P}=\frac{\mathrm{F}}{\mathrm{N}} \times 100 \%
$$

$$
\begin{array}{ll}
\mathrm{P} & : \text { The class percentage } \\
\mathrm{F} & \text { : Total percentage }
\end{array}
$$

Jurnal Ilmu Sosial dan Pendidikan

\section{Research Findings and Discussion}

This research was conducted in one cycle. There were eight meetings of this research. In the first meeting the researcher gave students the pre-test. The pre-test that was be held on Saturday 2 March 2019 and the researcher gave students action in second meeting up to seventh meeting that were be held on 4, 9,11,16, 18, 23 March 2019, in the last meeting the researcher gave post-test for students that was be held on Monday 25 March 2019. This research was successful in cycle 1 so the researchers do not need to continue to the next cycle.

\section{Before Implementing the Classroom Action Research:}

1. Preliminary of the Study

The researcher conducted observation to know the real problem that coming from XI SMA IPS in general especially in speaking based on the teacher's explanation in a view days ago when the researcher conducted an interview with an English teacher at SMAS Darul Hikmah Mataram.

When the researcher did the observation the researcher observe the students' activities during the learning process, and the researcher found some problem, the problems were the students understand with the instruction that given by the researcher but then, they do not know on how they will show their ideas orally, because they feel afraid to speak in English because they think about sentence structure they also do not know on how to say it in English because they still lake in vocabularies.

2. The Result of Pre-test

In this phase, the researcher shows the result of pre-test. The re-test conducted at the first meeting on Saturday 2 March 2019. In which the researcher gave the students such five different pictures of tourisms place in Lombok and 
asked them to describe it based on their own opinion about it. The purpose of giving them pre-test was to know the ability of students' speaking in performing their own ideas and to know their personal score how far their own understanding able to calculated from their individual score from this pre-test. The researcher calculated the students' pre-test result based on the formula from Grant Henning in sukar's thesis, (2017: 30) as follow:

$$
Y=\frac{X}{C} x 100
$$

Where:

$\mathrm{Y}=$ The percentage score

$\mathrm{X}=$ The raw score

$\mathrm{C}=$ The total number of items (highest possible score)

Table 4.1

Students Score of Pre-test

\begin{tabular}{|c|c|c|}
\hline No & Name & Score \\
\hline 1 & M & $\mathbf{3 6}$ \\
\hline 2 & SN & 24 \\
\hline 3 & ZR & 24 \\
\hline 4 & SY & 28 \\
\hline 5 & Y & 28 \\
\hline 6 & EW & $\mathbf{6 8}$ \\
\hline 7 & IF & 20 \\
\hline 8 & SA & 20 \\
\hline 9 & UD & 20 \\
\hline 10 & ZF & 24 \\
\hline 11 & FAH & $\mathbf{7 6}$ \\
\hline 12 & DKT & 40 \\
\hline 13 & SNR & 48 \\
\hline 14 & AK & $\mathbf{6 0}$ \\
\hline 15 & WH & $\mathbf{7 6}$ \\
\hline 16 & SB & $\mathbf{7 6}$ \\
\hline 17 & RH & $\mathbf{6 0}$ \\
\hline 18 & SR & $\mathbf{7 6}$ \\
\hline 19 & J & $\mathbf{5 2}$ \\
\hline & Total & $\mathbf{8 5 6}$ \\
\hline
\end{tabular}

Based on the table above, the researcher calculates the mean scores of Pretest with following the formula:

The mean score of pre-test was

$$
\mathrm{M}=\frac{\sum \mathrm{x}}{N}
$$

Notation : $\sum \mathrm{x}=856$

Jurnal Ilmu Sosial dan Pendidikan

$$
\mathrm{N}=19
$$

Calculation : $M=\frac{856}{19}=45.05$

The second step was to know the percentage of students' score who pas the KKM (75), and the researcher calculated as follow:

Percentage of students learning achievement in pre-test

$$
\begin{aligned}
\mathrm{P} & =\frac{F}{N} X 100 \% \\
\mathrm{P} & =\frac{4}{19} X 100 \\
& =21.05 \%
\end{aligned}
$$

Based on the result of pre-test means score of students were 45.05 and the result of the pre-test students means score still has under the minimum of mastering criterion. The lowest score was 20 and the highest score was 76 and the students score percentage was $21.05 \%$ from the result of the pre-test. The researcher concluded that the students' speaking performance were low because the result was not reach the criterion (KKM).

\section{Implementing the Classroom Action Research:}

Finding of the Cycle

The data in this cycle was obtained from the test, observation sheet, and recording.

1. The data obtained from the test

After giving the treatment the researcher gave the students' test, in which the researcher called it as the post test, to know the improvement of the students' result after giving the treatment using the autoplay media itself.

Table 4.2

Students Score of Post-test

\begin{tabular}{|c|c|c|}
\hline No & Name & Score \\
\hline 1 & M & 76 \\
\hline 2 & SN & 76 \\
\hline 3 & ZR & 76 \\
\hline 4 & SY & 76 \\
\hline 5 & Y & 76 \\
\hline 6 & EW & 80 \\
\hline 7 & IF & 76 \\
\hline 8 & SA & 72 \\
\hline 9 & UD & 72 \\
\hline 10 & ZF & 76 \\
\hline 11 & FAH & 96 \\
\hline
\end{tabular}


After doing the test, the

\begin{tabular}{|c|c|c|}
\hline 12 & DKT & 72 \\
\hline 13 & SR & 96 \\
\hline 14 & SNR & 72 \\
\hline 15 & AK & 76 \\
\hline 16 & WH & 92 \\
\hline 17 & SB & 88 \\
\hline 18 & RH & 80 \\
\hline 19 & J & $\mathbf{8 0}$ \\
\hline \multicolumn{2}{|c|}{ Total } & 1.508 \\
\hline
\end{tabular}

There are two step that used by the researcher to found the data from the students' test result, the first one is from the Mean score. The formula as follow:

$$
\begin{aligned}
& \qquad M=\frac{\sum \mathrm{X}}{\mathrm{N}} \\
& \text { Where: } \\
& \begin{aligned}
& \sum \mathrm{X}=1.508 \\
& \mathrm{~N}=19 \\
& \text { Calculation: } \mathrm{M}=\frac{1.508}{19} \\
&=79.36
\end{aligned}
\end{aligned}
$$

The second step is to know the percentage of the students score who ass the KKM (75), it calculated as follow:

$$
\begin{aligned}
\mathrm{P} & =\frac{F}{N} X \quad 100 \% \\
\mathrm{P} & =\frac{15}{19} \quad \mathrm{X} 100 \\
& =78.94 \%
\end{aligned}
$$

2. Data obtained from the observation sheet

a. First meeting

The first meeting was conducted on Saturday 2 March 2019. In which the researcher gave the students pre-test to know the students score especially in speaking. To start the meeting, the researcher greets the students, check the students' attendance list at the time. Here the researcher gave the students picture and asked them to describe it orally. Even like that the situation and condition inside the classroom itself was very crowded, some of the students are playing, some of the students are talking each other, and some of the students excuse to go to bathroom at the time. But the researcher tried to control the class as good as possible. forward to tell us about their opinion about the picture that they got based on their own understanding and the researcher do not forget to record them one by one.

b. Second meeting

The second meeting was held on Monday 4 March 2019 in which the researcher and the teacher come to the class. Before starting the lesson, the teacher and the researcher discuss about the material today and how it should be.

After coming, the teacher greets the students, check the attendance list of the students, and give the brain storming to the students related to the material, in which the material was about descriptive text.

The teacher explain the purpose of learning descriptive text itself, then the teacher started to explain the general about the descriptive text, followed by the example like picture, video that include inside the autoplay media itself.

Beside that the situation inside the classroom still un conducive because some of the students excuse going outside the classroom. Some of the students also pay attention to the projector because there was picture and video that shown by the teacher. So it can attract the students' attention to follow the lesson.

c. Third meeting

In this meeting, the teacher came to continue the previous topic that is about descriptive text. In which in this meeting the teacher focus to teach the students about classification of descriptive text, like describing something, someone, or even place. The teacher came to classroom started by greeting the students, check the students, and 
having a chat for a while about their condition at the time.

This third meeting was held on Saturday 9 March 2019. The teacher tried to ask the students describe about something around the classroom, to know the understanding of the students about the material that has been explained.

The teacher discuss with the students about on how to describe something around them. The teacher asked the students to give the question related to what they composed of, then the teacher clarified about the question that given by the teacher.

The teacher able to control the classroom, because there were some of them active to asked something they not understand with.

d. Fourth meeting

The next meeting was held on Monday 11 March 2019. In this meeting the teacher started to come to classroom by greeting the students, check the students as well. And the teacher asked the students about previous meeting while told them if in this meeting they were focus to discuss about on how to describe someone.

The purpose of the teacher to tough the students specifically about it, in order the students could understand well about the descriptive text itself.

The teacher shown the example like picture inside the autoplay media itself related to the human picture, in which the topic in this meeting was describing someone.

The students started to follow the teacher's rule, why i say so? Because the students follow the instruction that given by the teacher, like the students tried to show their opinion about the differences of describing something and someone.
The teachers gave the example about describing someone and discuss it together. In this meeting the teacher focused on the vocabularies that usually used in descriptive text.

The teacher drilling the vocabularies to the students in order the students able to pronounce it. After that the teacher asked the students to memorize it and conclude the meeting as the closing program.

e. Fifth meeting

The fifth meeting was held on Saturday 16 March 2019. The researcher came to the classroom without an English teacher cannot attend the class. The researcher as the teacher also observer at the time, in which the researcher discuss the material based on the teacher's command.

In this meeting, the researcher started the class by greeting the students, check the attendance list of the students and control the class as well. The researcher asked the last material to the students and asked the students how far they understand about it. Because the students able to answer the question from the teacher related to the previous material, the researcher goes on to the next topic that is describing animals.

The researcher explains on how to describe animals, then followed by the example. The researcher asked the students to asked question if they still composed about it.

The researcher asked the students to describe their favorite animal and practice it in front of the class. After that the researcher concluded the meeting and closed the program.

f. Sixth meeting

This meeting conducted on Monday 18 March 2019. In this meeting the teacher started the class 
like usually, greet the students, check the students and handle the situation of the classroom itself.

In this meeting the researcher want to say how far the understanding of the students itself by asking the students about all of the material that have been teaching. The teacher saw most of the students are active and pay attention full to the teacher by answering the teacher question about all of the material they understand.

Because there were some of students just listen without showing their idea about the material itself, the teacher invite the students to discuss again until they really understand about descriptive text itself, include on how to describe something, someone, place, or even animals.

The teacher concluded the lesson and asked the students to repeat all of the material because in the end of meeting, there will be test to know their score after giving the treatment.

g. Seventh meeting

This meeting what we called as the last meeting to give the treatments to the students. In which to see the students really really understand about all of the material and to make the students ready to pace the test, the teacher gave them exercise or quiz related to all of the material.

This meeting conducted on Saturday 23 March 2019. The teacher want to make all of the students comprehend all of the material that have been tough. Like usually the teacher started the class by greeting, check the students attendance list and gave them some picture include all of material and asked them to describe it bravely based on their understanding.
After finishing the exercise, the teacher discusses the result with the students, and again and again the teacher explains more all of the material. The teacher gave the full attention to the students who have low of understanding in order they could get high score in the end test.

The teachers concluded the meeting and remind the students to study harder about all of the material like they discuss in this last meeting.

h. Eight meeting

This was the last meeting which conducted on Monday 25 March 2019. In which in this meeting the researcher gave the posttest to the students to know the students improvement score after giving the treatments.

The researcher greet the students like usual and check the students complete or not. After all of the students complete, the researcher asked the students to be ready because today will be done test as the last meeting.

The researcher divides the different picture to the students and asked the students describe it orally in front of the classroom. The researcher do not forget to record the students because recording also one of the instrument that used by the researcher.

\section{Data obtained from recording}

Based on the result of data recording, the researcher concluded it that the result of data recording for pre-test that spent time for about 04 minutes and 41 seconds because there, every students tried to speak that containing one up to two sentences only. The students composed to show their idea about something in what way and so on.

While the result of post-test recording, that sent time for about 21 minutes and 36 seconds, because the students have already got the treatment so 
they know on how to describe something and they able to perform it orally based on their understanding. It is not for about one or two sentences for every students but for about one up to four paragraph instead.

So the researcher concluded that this research was successful because we can see from the three result of instrument here such as: test, observation sheet, and recording. And the mean score of the students more than KKM score of SMAS Darul Hikmah Mataram that is 75 .

\section{CONCLUSION AND SUGGESTION Conclusion}

The researcher at this season concluded that the use of autoplay media could increase the students' speaking performance at SMAS Darul Hikmah Mataram especially for the XI IPS. It supported by the result in every meeting was better, it also supported by the result of Mean in post test was 79.36 and the percentage was $78.94 \%$. It means that using autoplay media could improved students' speaking performance at SMAS Darul Hikmah Mataram.

Most of the students claimed that using autoplay media also made them enjoyed the learning process because many kinds of media could supported them to focus join the lesson like picture, video and so on. Beside that also autoplay media able to help the learning process easier for the students also the teacher. So from those statements the researcher concluded that the autoplay media suitable for the second grade students especially in teaching speaking.

\section{Suggestions}

Because the autoplay media as the new media in conducted the study using speaking, the researcher would like to give the suggestions as follow:

1. For the Teacher

The teacher should be creative in selecting the media to put inside the autoplay media itself like, picture, video or even kind of quiz, the teacher able to choose the model or background in making the autoplay media in order it can make the students enjoy the lesson.

2. For the Students

The students should more active in the classroom, like they should ask to teacher about something they do not understand with. The students also should often practice their English even in outside of the classroom, even though they just memories the vocabularies, speak English even little by little and something like that.

\section{For the Next Researcher}

The researcher hopes that the result of this research can be useful for the next researcher as the additional reference. And the researcher also hope that the next researcher able to make a research by using autoplay media but in different skill, because autoplay media able to help the learning process not just for the speaking class but also for the other lesson.

\section{REFERENCES}

Brown, H.D. 2001. Teaching By Principles An Interactive Approach to Language Pedagogy, London: Second Edition Longman, Inc.

. 2004. Language Assessment Principle and Classroom Practices. San Francisco, California.

Costello, P.J.M. 2003. Action Research. Great Britain By Biddles Ltd, King's Lynn, Norfolk.

Harianto, Sukar. 2017. The Use of Australs Debate in Improving Students' Critical Thinking Skill in Speaking. Thesis,IKIP Mataram. Unpublish.

Hernawati, Kuswari. 2010. Modul Pelatihan, Disampaikan Dalam Kegiatan PPM Dengan Judul: Pelatihan Pembuatan Media Pembelajaran Interaktif Dengan Perangkat Lunak Autoplay Media Studio Bagi Guru Sekolah Menengah di Laboraturium Komputer Jurdik Matematika FPMIPA UNY. 
Huges, A. 2003. Testing for Language Teachers. Cambridge University Press: UK.

Khairani, Zahratul. 2017. The Effectiveness of Students Team Learning (STL) Towards Self- Actualization and Speaking Competence at SMK Muhammadiyah Mataram Academic Year 2017/2018. Thesis, IKIP Mataram. Unpublish.

Kothari, C.R. 2004. Research Methodology. New Delhi: New Age International (P) Ltd., Publishers.

Louma, S. 2004. Assessing Speaking. Cambridge University Press: Newyork.

Marczyk, G., DeMatteo, D., \& Festinger, D. 2005. Essential of Research Design and Methodology. Canada: John Wiley \& Sons, Inc.

Melia, Gusti. 2012. An Analysis of Students' Speaking Performance in Class Presentation, 3.

Miles, M.B., Huberman, A.M., \& Saldana, J. 2014. Qualitative Data Analysis. USA: SAGE Publications, Inc.

Nasution, Saiful Hamzah. 2014. Media Pembelajaran. Disajikan dalam Workshop Pembelajaran Berbasis ICT dan Implementasinya Pada Kurikulum 2013. Matematika FPMIPA UNM: Malang.

Nisa, Khairun. 2017. Pengembangan Media Pembelajaran Berbantuan Aplikasi Autoplay Media Studio Pada Pokok Bahasan Fluida Dinamis di SMA. Fisika FKIP ULM: Banjarmasin.

Rumainur. 2016. Pengembangan Media Ajar Berbasis Multimedia Autoplay Studio 8 Dalam Pembelajaran Sejarah
Kebudayaan Islam Kelas XI MA Bilingual Batu Malang. Program Megister PAI Universitas Negeri Maulana Malik Ibrahim: Malang.

Sugiyono. 2007. Statistika Untuk Penelitian. Alfabeta: Bandung.

2015. Metode Penelitian Pendidikan. Alfabeta: Bandung.

Sudijono, Anas. 2009. Pengantar Statistik Pendidikan. PT RajaGrafindo Persada: Jakarta

Thornbury, S. 2005. How to Teach Speaking. Longman. 